Paper ID \#19173

\title{
A Quiet Revolution: Growth of Credentialed-Based Manufacturing Educa- tion in Florida
}

\author{
Dr. Marilyn Barger P.E., National Science Foundation ATE Centers
}

Dr. Marilyn Barger is the Principal Investigator and Executive Director of FLATE, the Florida Regional Center of Excellence for Advanced Technological Education, funded by the National Science Foundation and housed at Hillsborough Community College in Tampa, Florida since 2004. FLATE serves the state of Florida as its region and is involved in outreach and recruitment of students into technical career pathways; has produced award winning curriculum design and reform for secondary and post-secondary Career and Technical Education programs; and provides a variety of professional development for SETM and technology secondary and post-secondary educators focused on advanced technologies. She earned a B.A. in Chemistry at Agnes Scott College and both a B.S. in Engineering Science and a Ph.D. in Civil Engineering (Environmental) from the University of South Florida, where her research focused on membrane separation science and technologies for water purification. She has over 20 years of experience in developing curricula for engineering and engineering technology for elementary, middle, high school, and post secondary institutions, including colleges of engineering. Dr. Barger has presented at many national conferences including American Association of Engineering Education, National Career Pathways Network, High Impact Technology Exchange, ACTE Vision, League of Innovation and others. Dr. Barger serves on several national panels and advisory boards for technical programs, curriculum and workforce initiatives, including the National Association of Manufacturers Educators'Council. She is a Fellow of the American Society of Engineering Education, a member of Tau Beta Pi and Epsilon Pi Tau honor societies. She is a charter member of both the National Academy and the University of South Florida's Academy of Inventors. Dr. Barger holds a licensed patent and is a licensed Professional Engineer in Florida.

\section{Dr. Richard Gilbert, University of South Florida}

Richard Gilbert is a Professor of Chemical and Biomedical Engineering at the University of South Florida's College of Engineering . Richard is the Co-PI for the grant that supports the NSF designated Center of Excellence for Advanced Technological Education in Florida, FLATE. FLATE, now in its 13 year of operation, addresses curriculum, professional development, and outreach issues to support the creation of Florida's technical workforce. Richard has over 30 years of experience working with the K-14 education community. Other funded efforts include projects for the NIH and the US Department of Education. The latter was for the development of an engineering curriculum for elementary school applications. The former is for development of electric field mediated drug and gene applicators and protocols. This effort has generated over 20 patents and cancer treatment protocols currently in Phase II trials. Richard is a former US Air Force Office of Scientific Research Resident Research Scholar.

\section{Dr. Hugh Jack P.E., Western Carolina University}

Dr. Jack is not an author. The paper has been submitted on behalf of the authors Dr. Marilyn Barger and Dr. Richard Gilbert. 


\title{
A Quiet Revolution: Growth of Credentialed-Based Manufacturing Education in Florida
}

\begin{abstract}
Nationally, the revolution to include industry-driven and validated credentials in the mainstream manufacturing education platforms has barely begun, but educators and industry are digging in to find common grounds to use these tools to help close the growing manufacturing skills gap more efficiently and effectively. Serious conversations about using nationally recognized, third party validated, industry credentials to support career and technical education programs in Florida began early in the second half of the first decade of the twenty-first century. This paper discusses Florida initiatives that illustrate the evolution of aligning industry validated manufacturing skills based credentials with technical education programs in Florida.

Background

Relative to manufacturing related education in Florida, two independent directives; state legislative action and the National Manufacturing Association's Stackable Credential concept have driven the credential movement. The impetus for these directives was: the need to insert significant manufacturer identified skills into workforce; the anticipation of the "graying of the existing workforce"; and the accelerating impact of new technology being introduced onto the manufacturing floor. Superposition of these three influences generated the incentive to alter the footprint of Florida's Career and Technical Education (CTE) manufacturing education platform.

The Career and Professional Education (CAPE) Act in 2006 directed the Florida Department of Education (FLDOE) to restructure its Career and Technical Education (CTE) Division to address the alignment of industry defined skills needs to the instructional content in CTE programs. The goal was to have CTE programs directly address industry needs by aligning these programs to industry recognized credentials. The intended outcome was the creation of a high school graduate with an appropriate industry credential who would be more employable immediately upon graduation. Additional goals of the legislation included increasing the number of students that completed high school with job-ready skills and increasing the overall graduation rate. To achieve these goals, legislation directed the Florida Department of Education (FLDOE) to increase the rigor of the industry-aligned CTE programs, additional alignments to academic requirements, credentialing educators and using defined workforce needs for adopted programs. Although the short-term intent was meritorious, the greater long-term impact of this legislation identifies its contribution to Florida's manufacturing education structure.
\end{abstract}


The CAPE Act required that the Florida Department of Education identify the important third party validated industry credentials that have positive impact on technical performance of manufacturing employees. These credentials would also be aligned to an appropriate A.S. Degree program within the State College System. The CAPE Act accelerated the implementation of these high school career academies that could acquire significant additional state funding. Tiered bonus funding was defined for degrees of implementation of the defined criteria. The criteria for a "Gold Star Career Academy" included: 1) documented local workforce needs; 2) alignment to an industry-endorsed credential achievable by high school students; 3) teacher and student credentialing; 4) implementation of industry advisory committees; and 5) articulations to associate of science degree programs in the state.

At the National level, the National Manufacturing Association (NAM) also recognized the deleterious impact of retiring skilled workers and a growing skills gap. Their counter measure

\begin{tabular}{|l|}
\hline Occupation Related \\
Management Occupational \\
Competences Specific Requirements \\
Occupational Specific Competencies \\
Technical Competencies \\
Knowledge Competencies \\
Core Technology Related \\
Industry Specific Technical Competencies \\
Industry-Sector Technical Competencies \\
Foundation Related \\
Workplace Competencies \\
Academic Competencies \\
Personal Effectiveness
\end{tabular}

Table 1 Competences List contribution was the development of a Stackable Credential System with a structure based on skills and occupation categories established by the United States Department of Labor. The goal for NAM and its Manufacturing Institute was to provide clear pathways through the acquisition of knowledge and skills that effectively and efficiently leads to the production of a technical workforce that meets manufacturer's needs. NAM recognized credential sets align with competences needed in manufacturing. Table 1 shows the ascending progression of these competencies. The Stackable Credential System that incorporate these competences include only third party validated credentials and those endorsed by its large national membership. The credentials were aligned to defined levels of the Department of Labor's Competency Models and loosely to academic and technical education levels. The idea was to showcase that there were many ways to enter the manufacturing workforce and many opportunities to build a good and long-term career. The models would include multiple educational career pathways with various In/Out points; continuous skills and knowledge acquisition; "Earn \& Learn" integration of job and education/training; and recognized benchmarks that define progress (the industry-validated credentials). The complete competency NAM pyramid includes details at each of Table 1 "Related" platforms. These details can be viewed at http://www.careeronestop.org/CompetencyModel/pyramid.aspx?HG=Y .

In summary, a potential dilemma in Florida was clear. Technology is pushing skill change faster than curriculum can keep pace but manufacturing curriculum and programs builds the skilled workforce. By the middle of the last decade, the existence and merit of industry developed and recognized skills based credentials reached the mainstream conciseness of Florida's education system administrators responsible for the creation of that manufacturing workforce. The FLDOE was now armed with a Florida legislative mandate and the NAM-defined model of Stackable Credentials to change the face, content, and intent of manufacturing CTE programs in the high 
school, post-secondary adult vocational education (PSAV), and the Florida College System. The actual "boots-on-the-ground" transformation of these educational structures was significantly facilitated with resources provided by the National Science Foundation to the Florida Advanced Technological Education Center of Excellence (FLATE).

Florida's Credential Based Revolution Begins

FLATE, as a National Science Foundation Advanced Technological Education Center of Excellence for manufacturing education in Florida, recognized from its inception in 2002 that to execute a reconstruction of Florida's A.S. degree programs that would support advanced manufacturing and its related sectors required an innovative approach. FLATE quickly identified the enormous impact the CAPE legislation could have. The legislation implied that with a proper academic vehicle, industry credentials would be an alignment tool that would be an immediate connector for high school, adult education, and state college programs that supported manufacturing education. FLATE's approach was to develop a two year A.S. Engineering Technology degree program that would: consolidate various A.S. degree programs within the Florida College System; provide a statewide recognizable single target degree program for high school graduates to pursue manufacturing careers; incorporate seamless clearly defined articulation for industry validated FLDOE recognized credentials; quickly bring high school and college taught knowledge and skills in line with declared industry needs; and strengthen the statewide merit of locally recognized individual college supported College Credit Certificates.

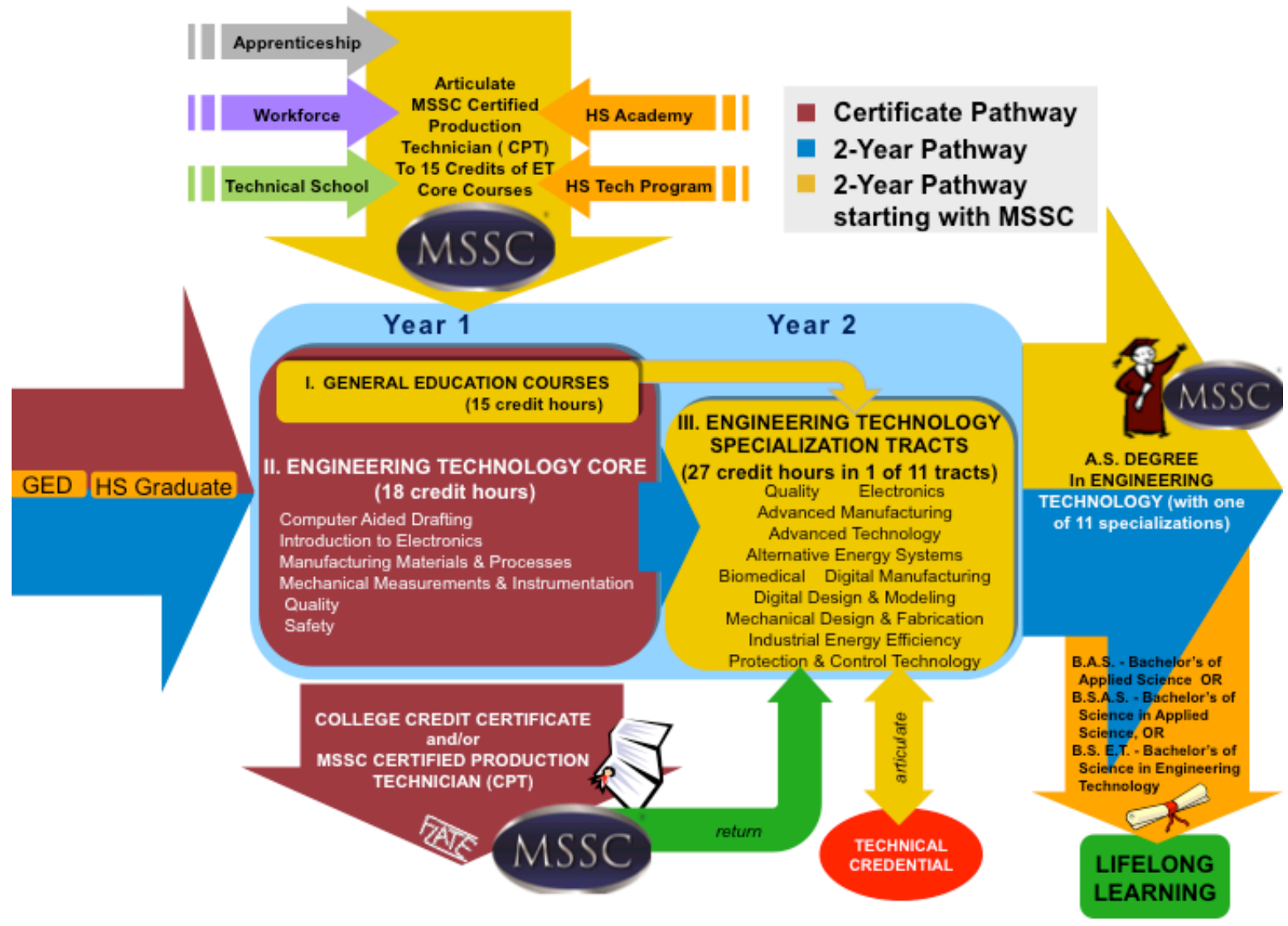




\section{Figure 1: Florida's Credential Structured Pathways for Manufacturing Education}

Figure 1 illustrates this multipurpose and flexible degree program. The heart of this course of study is to produce advanced technicians that will satisfy Florida's manufacturing needs. This two year curriculum as depicted was designed, developed, and deployed by FLATE using NSF resources as a state wide mechanism to create the technician workforce with the skills and knowledge Florida manufacturing requires. This program is now offered within 19 colleges in the Florida College System and maintained via a set of FLDOE Curriculum Frameworks monitored and amended by the FLDOE Division of Adult and Career Education. This specific illustration highlights the MSSC credential as an industry-supported credential alignment and articulation example.

Two entry pathways into the A.S. Engineering Technology degree program are emphasized. The top entrance arrow includes the important new mechanisms that the FLDOE now supports. These include apprenticeship programs, high school career academies, technical programs, and nationally recognized industry credentials like the Manufacturing Skills Standards Council (MSSC) Certified Production Technician (CPT). The entry arrow from the left continues to support the duel traditional high school and general education diploma (GED) path. Both of these pathways establish students in the first year of the Engineering Technology program.

This first year is accented by the Florida College System general education expectations plus the technology "core" curriculum. The content of this curriculum core are completely based in the statewide collective feedback from the manufacturer's that are members of individual college advisory committees. The MSSC-CPT was consciously and specifically targeted as the first industry credential to be integrated into the ET degree program because it was also achievable by high school students in an appropriate manufacturing CTE program (Automation and Production Technology) providing the basis of the first CAPE Act defined statewide articulation. The skill expectations of a CPT complemented and personalized for the students the knowledge and skill deliverables from the high school's technical curriculum and provide the secure foundation for a post-secondary advancement to more advanced technology and skills. That decision also allowed each of the colleges to move their specific knowledge and skills expertise into a concentrated 30 credit hour delivery package in the second year of study. In turn, this provided the mechanism to incorporate industry credentials positioned higher in the NAM Stackable Credential pyramid and also specialize in a define educational tract to support specific industry sectors that are found in a particular college's region. Today FLATE has installed or nearly completed the installation of several credentials within the statewide A.S. ET degree program.

Current specialization options in the A.S. Engineering Technology Degree are listed in the orange box (III Engineering Technology Specialization Tracts in year 2 of Figure 1). The curriculum structure for Florida's A.S. Engineering Technology inserts industry credentials into 
the degree's specializations. The 60 credit hour limit on the degree provides the second year's 27 to 30 credit hours for these specializations. This procedure creates a focused exposure to the credential's ascending skill acquisition expectations. This ET degree provides a statewide model of industry credentialed curriculum plus the checks and balances provided within the FLDOE education structure. Both attributes assure the quality and consistence of manufacturing education in Florida.

Table 2 summarizes an example of a single college's approach to a stacked credential pathway. The information was acquired from program documentation generated by Lorain County Community College in Elyria Ohio. The pathways presented reflect the options within welding careers and are representative of credential included curriculum programs. Additional information about welding credentials is available from the NSF-ATE Center, Weld-Ed https://www.weld-ed.org/, which is also housed at Lorain County Community College.

\begin{tabular}{|c|c|c|c|c|}
\hline \multirow[t]{6}{*}{$\begin{array}{l}\text { foce Lorain County } \\
\text { Community College }\end{array}$} & \multicolumn{4}{|c|}{$\begin{array}{l}\text { Aligned Education, Credential and Career Pathways } \\
\text { For the Welding Industry at Lorain County Community College }\end{array}$} \\
\hline & $\begin{array}{l}\text { Education } \\
\text { Pathway }\end{array}$ & $\begin{array}{l}\text { Credential } \\
\text { Pathway }\end{array}$ & $\begin{array}{l}\text { Career } \\
\text { Pathway }\end{array}$ & $\begin{array}{c}\text { Employer } \\
\text { Job Title/Wage Range }\end{array}$ \\
\hline & $\begin{array}{l}\text { B.S. } \\
\text { Science/Engineering }\end{array}$ & $\begin{array}{l}\text { SME Engineering } \\
\text { Technology }\end{array}$ & $\begin{array}{l}\text { Welding } \\
\text { Engineering }\end{array}$ & $\begin{array}{l}\text { Automation } \\
\text { Welding Mgr. }\end{array}$ \\
\hline & $\begin{array}{l}\text { Ohio State } \\
\text { University }\end{array}$ & $\begin{array}{l}\text { ASME Section } \\
\text { 9/API } 1104\end{array}$ & $\begin{array}{l}\text { Welding } \\
\text { Technology }\end{array}$ & $\begin{array}{l}10-15 \text { years. } \\
\text { Experience }\end{array}$ \\
\hline & $\begin{array}{l}\text { Cleveland State } \\
\text { University }\end{array}$ & $\begin{array}{l}\text { AWS D1.1/CWI } \\
\text { MSSC-CPT }\end{array}$ & & \$18- \$22 /hour \\
\hline & $\begin{array}{l}\text { Associate of Applied } \\
\text { Science }\end{array}$ & $\begin{array}{l}\text { AWS D1.1 Multiple } \\
\text { Processes/CWI }\end{array}$ & $\begin{array}{l}\text { Welding } \\
\text { Technology }\end{array}$ & $\begin{array}{l}\text { Welderl } \\
\text { Fabricator }\end{array}$ \\
\hline \multirow[t]{4}{*}{$\begin{array}{l}\text { Lucrative welding } \\
\text { career pathways }\end{array}$} & $\begin{array}{l}66 \text { Credit hrs. } \\
2 \text { yrs. Full time }\end{array}$ & MSSC-CPT & $\begin{array}{l}\text { Manufacturing } \\
\text { Engineering }\end{array}$ & $\begin{array}{l}5-10 \text { years } \\
\text { Experience }\end{array}$ \\
\hline & $\begin{array}{l}\text { Day/evening \& } \\
23 \text { Courses }\end{array}$ & NCRC & dugy & \$18- \$22 /hour \\
\hline & $\begin{array}{l}\text { One Year Technical } \\
\text { Certificate }\end{array}$ & $\begin{array}{l}\text { AWS D1.1 Multiple } \\
\text { Processes/CWI }\end{array}$ & $\begin{array}{l}\text { Welding } \\
\text { Entry Level }\end{array}$ & Welder/MIG/ \\
\hline & $\begin{array}{l}27 \text { Credit hrs. } \\
1 \text { yrs. Full time }\end{array}$ & MSSC-CPT & Welder/Cutter & $\begin{array}{l}0 \text { years } \\
\text { Experience }\end{array}$ \\
\hline National Career & 14 Courses & NCRC & & \$10-\$16 /hour \\
\hline $\begin{array}{l}\text { Readiness Certificate } \\
(\mathrm{NCRC})\end{array}$ & $\begin{array}{l}\text { Short Term Technical } \\
\text { Certificate }\end{array}$ & $\begin{array}{l}\text { AWS D1.1 Multiple } \\
\text { Processes/CWI }\end{array}$ & $\begin{array}{l}\text { Welding } \\
\text { Entry Level }\end{array}$ & $\begin{array}{l}\text { Welder/MIG/ } \\
\text { Repair }\end{array}$ \\
\hline $\begin{array}{l}\text { High school/ work(life } \\
\text { experience) }\end{array}$ & $\begin{array}{l}19 \text { Credit hrs. } \\
1 \text { yrs. Part time } \\
8 \text { Courses }\end{array}$ & NCRC & & $\begin{array}{l}\text { 3- } 5 \text { years } \\
\text { Experience } \\
\$ 10 / \text { hour }\end{array}$ \\
\hline
\end{tabular}

Table 2 Example of an Individual College Stacked Credential Welding Program

Credential Impact

The addition of "hands-on" manufacturing specific skill development in an education program that supports the creation of the advanced manufacturing workforce is valuable. Table 2 includes Lorain Community College value estimates of their pathway options. A formal 
investigation of credential stimulated career advancement is now being undertaken. The Illinois Community College Board (ICCB) is addressing this question. The MSSC-CPT credential is one tract of this study. Records were matched against Illinois tax returns for over 800 community college student level performance files. The data indicated a \$5,000 quarterly income just before vs. a \$7,000 average two quarters after program completion. Additional details and the status of this study are available from Jay Brooks, Director of Research and Policy Studies, jay.brooks@illinois.gov.

\section{Summary}

Industry recognized third party validated credentials have an intimate role to play in Florida's CTE education sphere. Legislative action plus resources from the National Science Foundation have resulted in FLDOE supported credential inclusive education platforms in high school, postsecondary adult vocational education, and the A.S. Engineering Technology degree program in the Florida College System. Broader impacts of this A.S. degree include: emphasizing seamless integration of technician education and certification-based training to produce lucrative manufacturing career pathways; increasing high school involvement in technician education; and increasing the impact on industry/education professional development and outreach interactions statewide. The A.S. Engineering Technology degree in Florida also has seamless articulated pathways to B.S. Applied Science and B.S. Engineering Technology degree programs offered at several colleges across Florida.

Elsewhere in the United States, the movement to include industry credentials in technical education also continues to expand in respond to the growing need for more of the nation's workforce to have the advanced knowledge and skills acquired through structured postsecondary education and training. Funding provided by the Department of Labor's Trade Adjustment grants to community colleges nationwide for workforce education and training provided targeted resources for colleges to review their education systems and streamline technical education with flexible pathways, On/Off ramps, and alignment to industry driven credentials in many occupational areas. Depending on the education and training structures, the Stackable Credential system might appear different. However, the target outcomes: better alignment to industry needs; more flexible and accessible post-secondary workforce education systems; third-party validated curriculum; and more strategic/systematic use of credit for prior learning characterize the goal for these allocated funds. 